\title{
Clinicopathological diagnosis and therapeutic management of sarcoptic mange in a rabbit and cat
}

\author{
Maneesh Sharma ${ }^{1 *}$, Babu L. Jangir ${ }^{2}$, Tarun Kumar ${ }^{1}$, \\ and Rajesh Khurana ${ }^{1}$ \\ ${ }^{1}$ Department of Veterinary Clinical Complex, College of Veterinary Sciences, Lala Lajpat Rai University of \\ Veterinary and Animal Sciences Hisar (Haryana), India \\ ${ }^{2}$ Department of Veterinary Pathology, College of Veterinary Sciences, Lala Lajpat Rai University of Veterinary \\ and Animal Sciences Hisar (Haryana), India
}

SHARMA, M., B. L. JANGIR, T. KUMAR, R. KHURANA: Clinicopathological diagnosis and therapeutic management of sarcoptic mange in a rabbit and cat. Vet. arhiv 88, 863-869, 2018.

\section{ABSTRACT}

Mites cause several skin conditions, such as demodectic, sarcoptic, psoroptic and notoedric mange. This study presents the clinicopathological findings of sarcoptic mange in a rabbit and cat, and its therapeutic management. One non-descript male rabbit and one female cat, housed together in the same premises were presented to the Veterinary Clinical Complex, Lala Lajpat Rai University of Veterinary and Animal Sciences, Hisar with a history of alopecia, anorexia, intense itching, erythema, dandruff and whitish dry crust-like lesions on their ears, nose, face, and the areas surrounding the ears and eyes. Microscopic examination of skin scrapings from different sites confirmed sarcoptic mange. They were successfully treated with ivermectin and fipronil spray in intervals of 15 days, along with supportive therapy.

Key words: cat; clinicopathological; fipronil; ivermectin; rabbit; sarcoptic

\section{Introduction}

Mites cause several skin conditions such as demodectic, sarcoptic, psoroptic and notoedric mange. Scabies is a contagious skin infection caused by the mite Sarcoptes scabiei (S. scabiei). Rabbits may be infested with a variety of mites, such as ear mites, fur mites or burrowing mites. Sarcoptes sp. are deep burrowing mites that affect the ears, nose, feet and areas around the genitalia (KACHHAWA et al., 2013). They cause intense itching, puritius, pyoderma, crust and scar formation, and thickening and wrinkling

\footnotetext{
*Corresponding author:

Assist. Prof. Maneesh Sharma, Veterinary Diagnostic Laboratory, Department of Veterinary Clinical Complex, College of Veterinary Sciences, Lala Lajpat Rai University of Veterinary and Animal Sciences Hisar 125004 (Haryana), India, E-mail: drmaneeshvet@gmail.com
}

ISSN 0372-5480

Printed in Croatia 
of the skin in the affected areas. Mites generally spread from rabbit to rabbit either by direct contact or contact with an infected environment (PANIGRAHI and GUPTA, 2013). They may also spread from rabbit to cat or other pet animals if they are kept in the same premises. Severe infection, especially in young or debilitated animals, causes high mortality (SAMUEL et al., 2001). Overcrowding and poor hygienic conditions are significant factors for infection with S. scabiei mites (McCARTHY et al., 2004). Visual examination is not sufficient to confirm the presence of mites. Therefore, microscopic examination of skin scrapings is an appropriate method for diagnosis of mites. Infestation of sarcoptic mange, if left untreated, may cause significant morbidity and economic loss in animals. The present communication describes the clinicopathological diagnosis and successful therapeutic management of sarcoptic mange in a rabbit and cat.

\section{Case presentation}

A non-descript male rabbit (1 year) and female cat ( 7 months) were presented to the Department of Veterinary Clinical Complex of the University at 10 days interval in the month of December, with a history of alopecia, anorexia, dandruff and intense itching. Clinical examination revealed skin lesions such as erythema, white indurated dry crusts and scabs on the ears, nose, face and eyes (Figs. 1, 2 and 3). History revealed that both the rabbit and the cat were kept in the same premises. The owner reported that the cat, housed in the same premises, also developed similar skin lesions after 15 days (Fig. 4).

Skin scrapings were collected from the affected parts of the body and processed for examination of the external parasites. Microscopic evaluation was performed as per the standard procedures described by SOULSBY (1982).

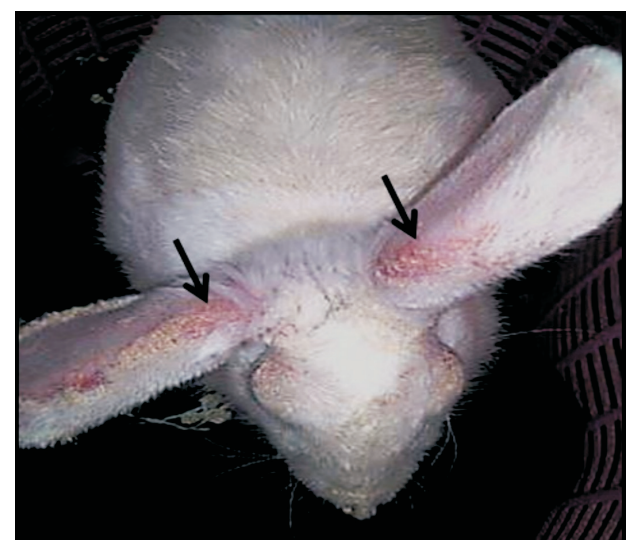

Fig. 1. Rabbit showing alopecia and erythema on the ear pinnae and face (arrow)

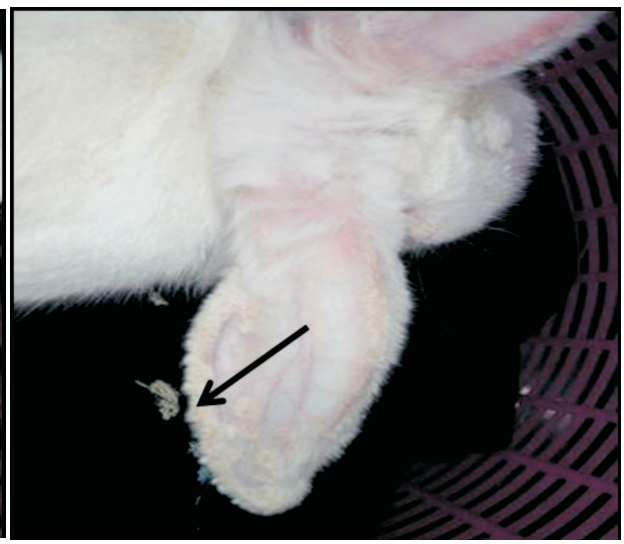

Fig. 2. Rabbit showing white indurated dry crust-like lesions on the margins of the ear pinna (arrow) 


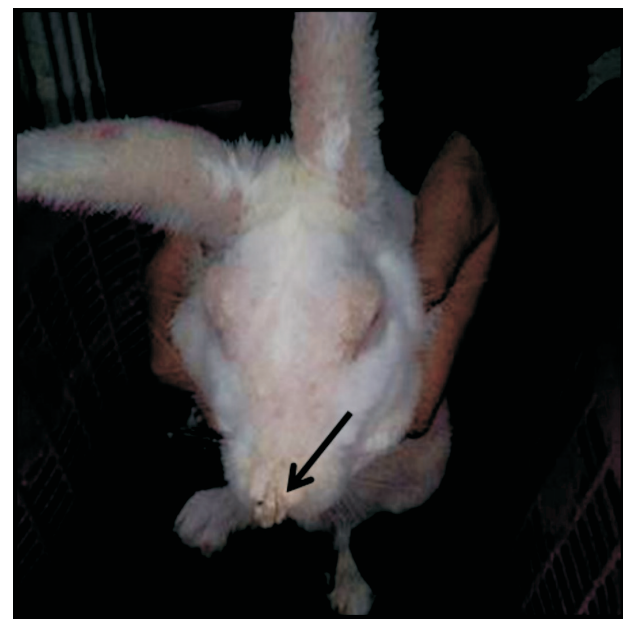

Fig. 3. Rabbit showing white crust-like lesions on the nose, mouth, face and around the eyes (arrow)

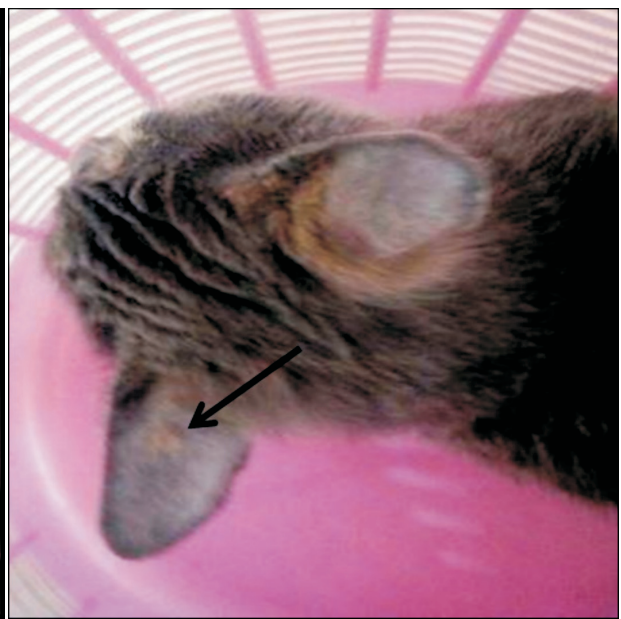

Fig. 4. Cat showing rough hair coat and whitish crust-like lesions on the ear pinna (arrow)

\section{Results and discussion}

S. scabiei infection is rare to uncommon in rabbits (PERCY and BARTHOLD, 2007). The present study describes the clinical findings, diagnosis and therapeutic management of sarcoptic mange in a rabbit and a cat. Microscopically, skin scrapings revealed adult parasites of Sarcoptes sp. measuring from 313 to $567 \mu \mathrm{m}$ in length, with the presence of short legs and a rounded body (Figs. 5, 6 and 7) and their ova (Fig. 8). The morphological characteristics, such as the presence of unsegmented suckers on the $1^{\text {st }}, 2^{\text {nd }}$ and $4^{\text {th }}$ pairs of legs in the case of males and $1^{\text {st }}$ and $2^{\text {nd }}$ pairs in the case of females were also observed. Spines on the dorsum and terminal anal opening were also noticed. Thus, on the basis of history, clinical manifestations and evidence of parasites in skin scrapings, both the rabbit and cat were diagnosed as having Sarcoptes infection. The presence of crusts and scab lesions on the head, ears and around the face in both cases is in agreement with the findings of earlier workers (DARZI et al., 2007; MITRA et al., 2014; GALDHAR et al., 2015). The morphological characters were similar to those reported by RADI (2004).

The rabbit was treated with two injections of ivermectin $(200 \mu \mathrm{g} / \mathrm{kg} \mathrm{b.m.} \mathrm{s/c)} \mathrm{at}$ a 15 day interval and cat was treated with fipronil spray. The supportive therapy of antihistaminic (Chlorpheneramine maleate $1 \mathrm{mg} / \mathrm{kg}$ b.m. orally/once in a day) and topical application of povidine iodine ( $5 \%$ aqueous solution) for five days was given to both the animals. Both the pets showed marked improvement and recovered completely after one month of treatment (Figs. 9 and 10). 
M. Sharma et al.: Clinicopathological diagnosis and therapeutic management of sarcoptic mange in a rabbit and cat

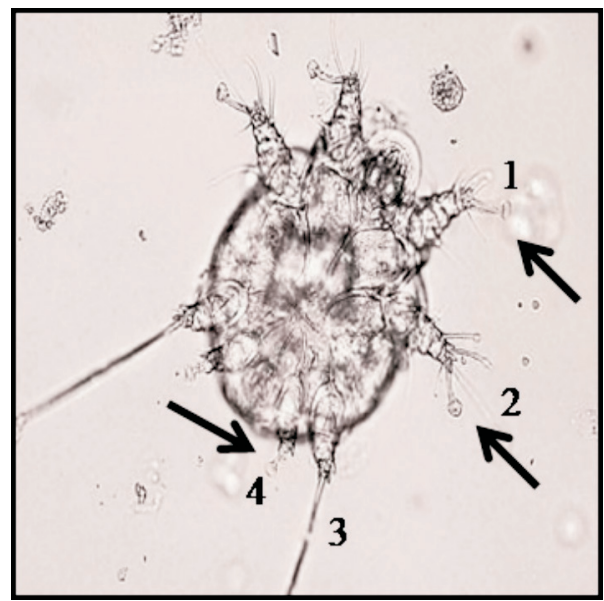

Fig. 5. Micro-photograph of male sarcoptic species showing three unsegmented suckers on the first (1, arrow), second (2, arrow) and fourth $(4$, arrow) pairs of legs. $\times 400$.

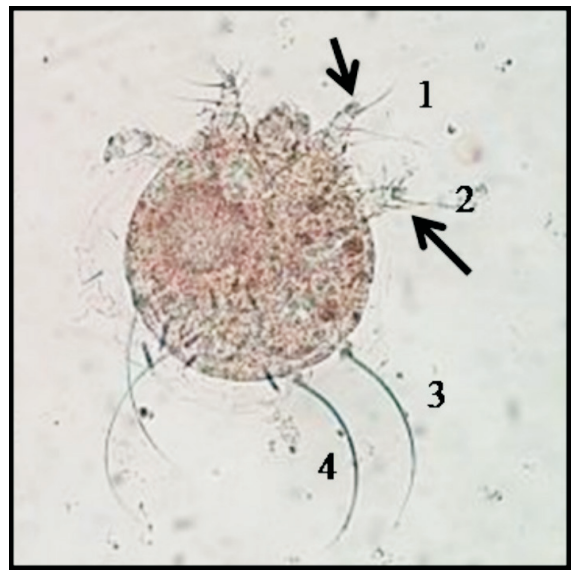

Fig. 7. Micro-photograph of female sarcoptic species showing two unsegmented suckers on the first (1, arrow) and second (2, arrow) pairs of legs. $\times 400$.

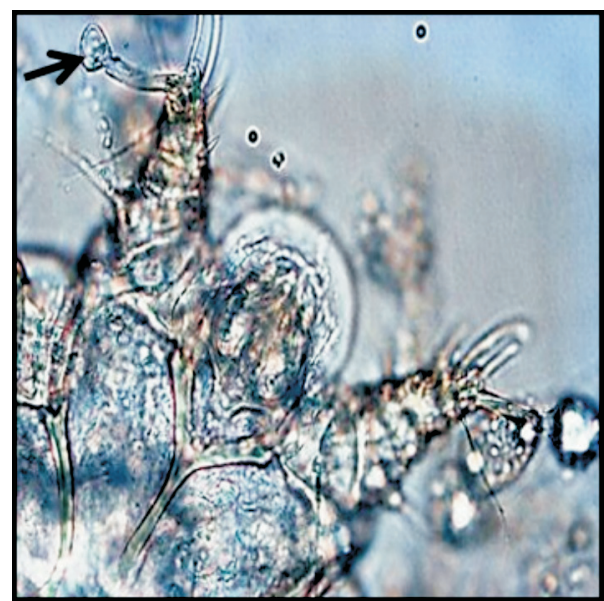

Fig. 6. Higher magnification of Fig. 5 showing an unsegmented sucker on the first leg (arrow). $\times 1000$.

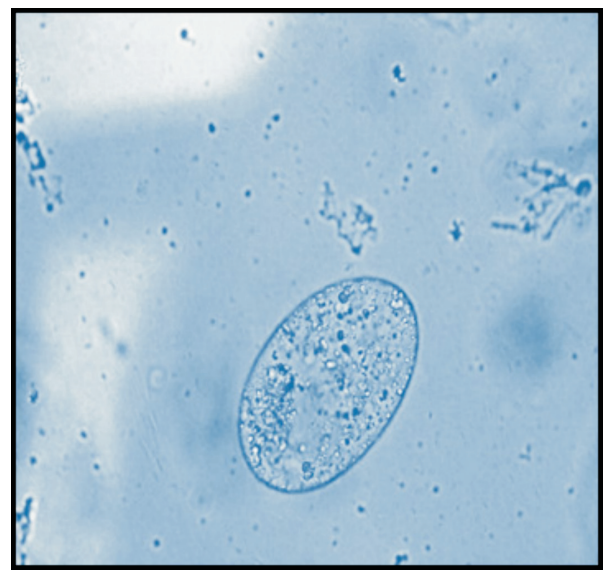

Fig. 8. Micro-photograph showing eggs of the sarcoptic species. $\times 400$. 
M. Sharma et al.: Clinicopathological diagnosis and therapeutic management of sarcoptic mange in a rabbit and cat

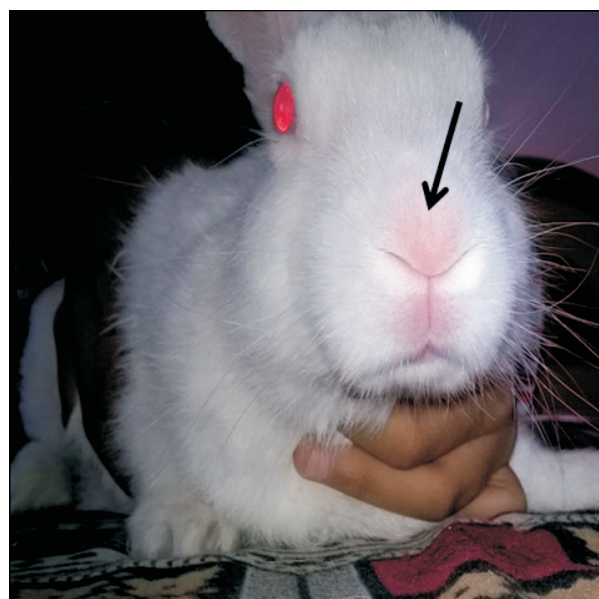

Fig. 9. The rabbit recovered after treatment, showing normal nose, mouth and face (arrow)

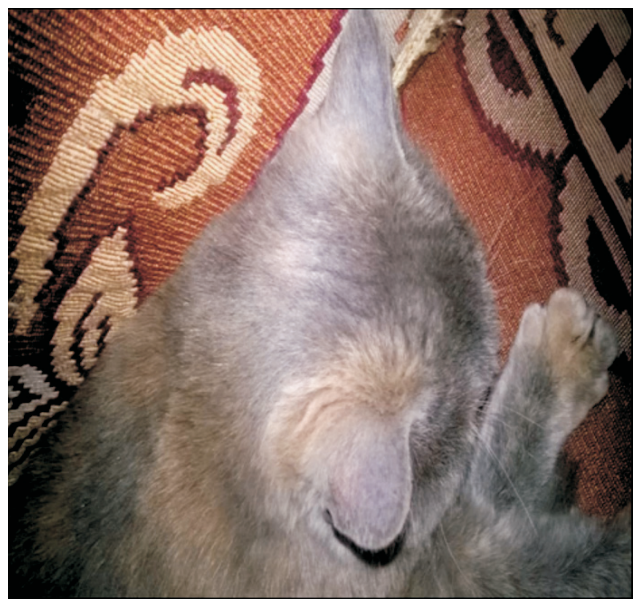

Fig. 10. Normal appearance of hair coat and ear pinnae of the recovered cat after treatment

The successful recovery of the rabbit with parenteral administration of ivermectin $200 \mu \mathrm{g} / \mathrm{kg}$ b.m. along with supportive therapy is in corroboration with the findings of earlier authors (DURDANE et al., 2010). Both cases presented during December, which is in accordance with the observations of earlier authors who reported that the winter months provide favorable climatic conditions for the development of all the life stages of Sarcoptes sp. mites, leading to a considerable increase in the mite population (ARLIAN et al., 1989).

From the present study, it may be concluded that scabies can be transmitted from rabbits to cats and vice-versa, if they are kept in common premises. In the present study, injections of ivermectin were sufficient to control the scabies infection in the rabbit, whereas, a single spray of fipronil alone was able to control the scabies in the cat.

\section{Acknowledgements}

The authors are thankful to the Head of the Veterinary Clinical Complex of the College of Veterinary Sciences, Lala Lajpat Rai University of Veterinary and Animal Sciences, Hisar, for providing the necessary facilities to carry out the present study.

\section{References}

ARLIAN, L. G., D. L. VYSZENSKI-MOHER, M. J. POLE (1989): Survival of adults and development stages of Sarcoptes scabiei var. canis when off the host. Exp. Appl. Acarol. 6, 181-187.

DOI: $10.1007 / \mathrm{BF} 01193978$ 
M. Sharma et al.: Clinicopathological diagnosis and therapeutic management of sarcoptic mange in a rabbit and cat

DARZI, M. M., M. S. MIR, R. A. SHAHARDAR, B. A. PANDIT (2007): Clinicopathological, histochemical and therapeutic studies on concurrent sarcoptic and notoedric acariosis in rabbits (Oryctolagus cuniculus). Vet. arhiv 77, 167-175.

DURDANE, K., I. TONAY, K. EFSUN, G. ENSARI, Y. OSMAN (2010): Comparison of efficacy of ivermectin and doramectin against mange mites (S. scabiei) in naturally infected rabbits in Turkey. Vet. Ital. 46, 51-56.

GALDHAR, C. N., P. S. KHANGAL, M. L. PAWAR, T. D. RASAL, S. U. DIGRASKAR (2015): Clinico-biochemical and therapeutic studies on notoedric mange in pet rabbits. J. Parasit. Dis. 39, 113-116.

DOI: $10.1007 / \mathrm{s} 12639-013-0277-6$

KACHHAWA, J. P., S. KACHHAWA, M. SRIVASTAVA, A. CHAHAR, N. SINGH (2013): Therapeutic management in rabbits. Intas Polivet. 14, 306-308.

McCARTHY, J., D. KEMP, S, WALTON, B. J. CURRIE (2004): Scabies more than just an irritation. Post. Grad. Med. J. 80, 382-387.

DOI: $10.1136 /$ pgmj.2003.014563

MITRA, J., R. N. SHIKARI, A. K. DAS, B. B. ROY, M. MITRA (2014): Therapeutic management of sarcoptic mange in rabbit with ivermectin. Explor. Anim. Med. Res. 4, 116-120.

PANIGRAHI, P. N., A. R. GUPTA (2013): Therapeutic management of concurrent sarcoptic and psoroptic acariasis in rabbits. Intas Polivet. 14, 319-321.

PERCY, D. H., S. W. BARTHOLD (2007): Pathology of Laboratory Rodents and Rabbits. Blackwell Publishing Professional, Ames, Iowa.

DOI: $10.1002 / 9780470344613$

RADI, Z. A. (2004): Outbreak of sarcoptic mange and malasseziasis in rabbits (Oryctolagus cuniculus). Comp. Med. 54, 434-437.

SAMUEL, W. M., M, PYBUS, A. A. KOCAN (2001): Parasitic Diseases of Wild Mammals. Iowa State University Press, Ames.

DOI: $10.1002 / 9780470377000$

SOULSBY, E. J. L. (1982): Helminthes, Arthropods and Protozoa of Domesticated Animals. $7^{\text {th }}$ ed., ELBS. Baillers Tindall, London. p. 490. 
M. Sharma et al.: Clinicopathological diagnosis and therapeutic management of sarcoptic mange in a rabbit and cat

\section{SHARMA, M., B. L. JANGIR, T. KUMAR, R. KHURANA: Kliničko-patološka} dijagnoza i liječenje sarkoptes-šuge kunića i mačke. Vet. arhiv 88, 863-869, 2018.

\section{SAŽETAK}

Grinje uzrokuju nekoliko kožnih bolesti među kojima se, ovisno o uzročniku, ističu demodeks-šuga, sarkoptes-šuga, psoroptes-šuga i notoedres-šuga. U radu su prikazani kliničko-patološki nalazi i liječenje neuobičajenog slučaja sarkoptes-šuge kunića i mačke. Mužjak kunića i mačka smješeteni su zajedno u istim prostorijama veterinarske klinike Fakulteta za veterinarske i animalne znanosti, Sveučilišta Lala Lajpat Rai, Hisar. U anamnezi oboljelih životinja su navedeni alopecije, anoreksija, intenzivni svrbež, eritem, perut te bjelkaste, suhe, krastolike lezije na i u okolini ušiju, nosa i lica. Mikroskopski pregled strugotina kože s različitih mjesta pokazao je odrasle parazite iz porodice Sarcoptidae i njihova jajašca. Životinje su tijekom razdoblja od 15 dana, uz potpornu terapiju, uspješno liječene ivermektinom i fipronil sprejom.

Ključne riječi: mačka; kliničko-patološki nalaz; fipronil; ivermektin; kunić; sarkoptes-šuga 
